\title{
THE EVIDENCE-BASED ARGUMENT IN PEER DISAGREEMENT*
}

\section{Elif KÜTÜKCÜ**}

\begin{abstract}
The problem of disagreement is one of the most important issues that have been debated in epistemology in recent years, and in particular the peer disagreement. The main question of this problem is what kind of attitude we should rationally adopt when we realize that someone who is an epistemic peer to us does not think the same. There are four main responses to this question: conciliationism, steadfastness, total evidence view, and justificationist view. According to conciliationism, when there is a peer disagreement, the parties should give equal weight to each other's beliefs, lower their confidence in their own beliefs or suspend their judgments on the issue in question. According to the steadfastness view, when there is a peer disagreement, one can continue to maintain one's own belief, and this is rational. In the total evidence view, one's total evidence in disagreement with an epistemic peer; consists of his own belief, the belief of his peer, and the evidence on which their belief before the disagreement is based. For this reason, according to Kelly, who is the owner of this view, it may be reasonable to place more weight on one's own belief if the original evidence supports his belief more than that of the peer. According
\end{abstract}

* This article was extracted from my doctoral dissertation's subject, "Religious Diversity and Epistemology of Disagreement", which I am currently studying on it.

** Ph.D. Student, Ankara University Institute of Social Sciences, Department of Philosophy and Religious Sciences. e-mail: elifcakmakkutukcu@gmail.com ORCID:0000-0002-6189-2095

Atıf/Cite as: Kütükcü, Elif. "the Evidence-Based Argument in Peer Disagreement" Dini Araştırmalar 24/61 (Aralık 2021), 281-296, https://doi.org/10.15745/da.990404 
to the justificationist view, the degree of your prior justification for the proposition in disagreement determines your response to it; namely, if you have a high degree prior justification you can maintain your belief as in the steadfastness view, but if you do not have a high degree prior justification, you need to revise your belief as in the equal weight view. In this article, first I will briefly examine these four views and deal with the points where they fail to satisfy. Later, I will argue that resolution of the disagreement should be case-based. And finally, I will present the evidence-based argument in peer disagreement which is my own response to this problem and explain it with sample cases.

Keywords: Disagreement, Peer Disagreement, Steadfastness, Conciliationism, Evidence

\section{Denk İhtilafında Delile Dayalı Argüman \\ $\ddot{O} z$}

Son y1llarda epistemolojide tartışılan önemli konulardan biri ihtilaf problemidir. İhtilaf problemi ise özelde denk ihtilafı üzerinden tartışılmaktadır. Epistemik olarak bize denk birinin bizimle aynı şeyi düşünmediğinin farkına vardığımızda, rasyonel olarak inancımızla ilgili nasıl bir tutum sergilememiz gerektiği bu problemin ana sorusudur. Bu soruya uzlaşmacılık, kararlılık, toplam kanıt görüşü ve gerekçelendirmeci görüş olmak üzere verilen dört ana cevap vardır. Bu makalede analitik bir yol izleyerek önce söz konusu görüşleri kısaca inceleyip onların problemi çözmekte yetersiz kaldığını ortaya koyacağım. Daha sonra denk ihtilafı probleminin çözümünde ihtilafın karmaşıklığı ve denklerin durumu gibi bir çok faktör etkili olduğundan ihtilafın çözümünün olgu bazlı olması gerektiğini savunaca$\breve{g} ı$. Ve son olarak, denk ihtilafı problemine verilmiş cevapların eksikliklerini içermeyen ve kendi cevabım olan denk ihtilafında delile dayalı argümanı ortaya koyup, onu olgu örnekleri ile açıklayacağım.

Anahtar Kelimeler: İhtilaf, Denk İhtilafı, Kararlılık, Uzlaşmacılık, Delil

\section{Özet}

Hayatın içinde başkaları ile aynı şeyi düşünmediğimiz bir çok olguyla karşılaşırız. İhtilaf ettiğimiz kişiye göre, ihtilaf edilen meseleyle ilgili 
ilk düşüncemiz, zaman zaman değişir. Örneğin konusunda uzman biriyle, uzman olduğu konu hakkında ihtilaf edersek genellikle ilk düşüncemizden/inancımızdan vazgeçeriz veya bizim daha uzman olduğumuz bir konu hakkında bizim kadar bilgili olmayan biriyle ihtilaf edersek inancımızdan vazgeçmeyiz. Peki ama bizimle denk biriyle ihtilaf edersek, ilk inancımızla ilgili nasıl bir tutum almamız gerekir? İşte epistemolojide son yıllarda tartışılan önemli konulardan biri ihtilaf problemidir ve bu problem özellikle denk ihtilafı ekseninde tartışı1ır.

Bir kişiyle epistemik olarak denk olmak; onunla deliller, epistemik erdemler ve bilişsel yetilerimizin doğru çalışması açısından denk olduğumuz anlamına gelir. Kendimize denk biriyle ihtilaf ettiğimizde ilk inancımızla ilgili nasıl bir tutum takınmamız gerektiği konusunda literatürde dört ana görüş vardır. Bunlar uzlaşmacılık, kararlılık, toplam kanıt görüşü ve gerekçelendirmeci görüştür. Uzlaşmacılık görüşü ve onun güçlü versiyonu olan eşit ağırlık görüşü, bir kişinin kendisine epistemik denk biriyle ihtilaf etmesi durumunda denginin inancına kendisininki ile eşit derecede doğruluk payı vermesi gerektiğini, kendi inancına olan güvenini düşürmesi gerektiğini ya da ihtilaf edilen konu hakkında yargısını askıya alması gerektiğini savunan görüştür. Bu görüşün en önemli açmazı kendi kriterini karşılayamamasıdır. Bununla birlikte özellikle felsefi, dini, siyasi ve ahlaki ihtilaflar gibi karmaşık ihtilaflarda kişinin net bir duruşunun olmasını imkansızlaştırması da uzlaşmacılık için bir diğer açmazdır. Kararlılık görüşü, kendimize epistemik olarak denk biriyle ihtilaf ettiğimizde kendi inanc1mızı devam ettirmemizin rasyonel olduğunu savunan görüş̧ür. Bu görüşle ilgili en önemli sorun, kendi inancımızı devam ettirmenin anlamsız olacağ 1 basit ihtilaflar diyebileceğimiz ihtilafların çözümünde yetersiz kalmasıdır. Ayrıca bütün ihtilaflarda kendi inancına devam etmenin epistemik egoizme kayabilecek bir tarafı olmakla birlikte, bu görüşü savunanların da epistemik denklikteki taraflar arasındaki simetriyi bozarak ihtilafa çözüm bulmaya çalışması tartışmalı olabilecek bir tavırdır. Kelly'e ait olan toplam kanıt görüşü, ihtilafın kendisine uzlaşmacılar kadar çok değer vermek ya da kararlılığı savunanlar gibi hiç değer vermemek arasında bir orta yol bulmaya çalışan görüştür. Kelly, ihtilafın farkına varılmasından önce tarafların sahip olduğu delillerin, ihtilaf sonraki tutumun belirlenmesinde dikkate alınması gerektiğini söyler. Bir bakıma önceki ve sonraki delillerin gücüne göre hareket edilmesi gerektiğini söyleyen toplam kanıt görüşünün, delilin gücünü belirlerken ihtilaf edilen kişi sayısını da dikkate alması delilin 
gücü konusunda doğru bir temel oluşturmadığı izlenimi yaratır. Lackey'e ait olan gerekçelendirmeci görüş ise kişilerin inançlarını gerekçelendirme derecesinin ihtilafın çözümünde belirleyici etmen olması gerektiğini savunur. İlk bakışta oldukça makul görünen bu görüş, Lackey'nin kullandığı örneklerle hatalarını ortaya çıkarır ve bu görüşte de gerekçelendirmenin gücünü belirleyen etmenin net olmadığg görülür.

İhtilafların çözümünde sözünü ettiğimiz dört ana görüşten uzlaşmac1lık ve kararlılık görüşleri için ayrıca meseleye toptan yaklaştıkları konusunda bir eleştiri de vardır. Yani bu görüşler bir çözümü, bütün ihtilaflar için uygulanabilir bir çözüm olarak sunarlar. Oysa gördüğümüz nesnenin ne olduğu gibi duyusal algılarımızla ilgili basit denilebilecek ihtilaflar olduğu gibi felsefi, siyasi, ahlaki veya dini konulardaki ihtilaflar gibi son derece çetrefilli ihtilaflar da vardır. Bu anlamda basit ihtilafların uzlaşmacılığı, karmaşık ihtilafların kararlılık görüşünü desteklediğini söyleyen Kirk Lougheed gibi isimler de vardır. Ancak bize öyle geliyor ki, ihtilafların çözümünde makul ve etkili yol ne toptancı yaklaşımla elde edilebilir ne de sadece ihtilafın karmaşıklığı ile ilgilidir. Bazen bir ihtilafta denklerden biri değiştiğinde de ihtilaf basitken karmaşık olabilir. Bu yüzden bu makale, ihtilafların çözümümün olgu bazlı olması gerektiğini savunmaktadır.

Denk ihtilafı problemine getirilen dört çözümün yetersiz kaldığı noktalar olduğu için, bu makale, probleme yeni bir çözüm önerisi getirmektedir. 'Denk İhtilafında Delile Dayalı Argüman' olarak adlandırdığım argümanın temelinde, kelam literatüründeki kat'i delil/zanni delil ayrımı vardır. Buna göre, karşıt ihtimallerin hepsini eleyen delil kat'i delil iken, eleyemeyen delil zanni delildir. 'Denk İhtilafında Delile Dayalı Argüman', tarafların sahip olduğu delillerin bu ayrıma göre sahip olunan delilin türüne ve kat'i delile ulaşmanın imkanına bakarak olgu bazlı ihtilaf çözümü sunar. Argüman, ihtilafın iki tarafının da zanni delile sahip olduğu, bununla birlikte kat'i delili elde etmenin imkanı söz konusu olduğu denk ihtilafı olgularında uzlaşmacılığın doğru seçenek olduğunu; yine ihtilafın iki tarafının da zanni delile sahip olduğu ancak kat'i delili elde etmenin imkanının söz konusu olmadığı denk ihtilafı olgularında kararlılık görüşünün doğru seçenek olduğunu savunur. Yine argümana göre, eğer denklerden biri kat'i delile sahipken, diğeri zanni delile sahipse yapılması gereken delilin üstün olduğu tarafın inancına uymaktır.

Özetle bu makalenin savunduğu 'Denk İhtilafında Delile Dayalı Argüman', epistemolojide son yıllarda öne çıkan bir problem olarak denk 
ihtilafı problemine getirilen çözümlerin eksik kaldığı yerleri tamamlamak adına yeni bir bakış açısı ortaya koyar. Bununla birlikte argümanın rölativizme destek sağlayabileceği düşünülse de, rasyonellik ile doğruluğun farklı anlamlara geldiği düşünülecek olursa, birbirine zıt şeylerin rasyonel olabilmesine rağmen doğru olmayabileceği mümkündür. Dolayısıyla argüman, rölativizmden uzaktır.

\section{Introduction}

We experience many cases in our daily life when we don't think the same with others. In almost every subject, it is not hard to find someone who does not think like us as an individual or a group. Disagreement is in all areas of life for all of us. But what does disagreement mean in epistemology? Doxastic options of a proposition can take three forms: believe, disbelieve, and suspend judgment. Incompatible doxastic attitudes between two people toward the same proposition are disagreement. Also, the different levels of confidence in a belief between two individuals are disagreement, too (Matheson, 2018, 1).

Disagreement in epistemology is mostly discussed over the subject of peer disagreement. In that the resolution of a disagreement we have with a child or a drunk, or a disagreement we have with an expert, is very simple. Because there is an obvious difference between our epistemic degrees. But what if we disagree with someone whose epistemic degree is equal to us? Interestingly, people with equal epistemic degrees reach different or opposite conclusions from the same evidence. Now let's look at what 'equal epistemic degree' means, i.e. who is a peer?

Although there are many different conceptions of epistemic peer in the literature, generally there are three conditions that make someone an epistemic peer:

(1) Faculty factors: Intelligence, reasoning ability, perceptual ability, etc.

(2) Evidential factors: Having the same or equally good evidence.

(3) Virtue factors: Open-mindedness, being intellectually courageous, etc. (Matheson, 2014, 317).

Here, if I will make an addition to the definition of epistemic virtue, epistemic virtue involves sincerely aiming for the truth. Then so, those who fulfil these three conditions are epistemic peers. 
The main question about peer disagreement is: what is the most reasonable response to a peer disagreement? If you realize that you disagree with someone who is your epistemic peer, can you rationally maintain your belief or should you revise your belief? Conciliationists/conformists argue that we should revise our beliefs in a peer disagreement. Non-conformists argue that we can maintain our beliefs. Between conformism and nonconformism there are two views that say sometimes we may response as conformists, sometimes as non-conformists. Definitely, these views tell us in which circumstances we can be conformists or non-conformists. We call them as total evidence view and justificationist view. However, there are some shortcomings of these four views. Therefore, I will first consider these views with their inadequacies and then put forward my own evidencebased argument, which I think does not contain those inadequacies.

\section{Four Views on Peer Disagreement}

One of the answers given by the philosophers who seek the most reasonable response to a peer disagreement is conciliationism/conformism, and the strongest type of conciliationism is the equal weight view. According to this view, peers should give equal weight to each other's beliefs. In a peer disagreement, conciliationism argues that both parties should revise their beliefs, lower confidence in their beliefs, or suspend their judgment. Many philosophers have defended conciliationism (See Christensen, 2007; Elga, 2007; Feldman, 2011; Matheson, 2015). Suspending judgment is a view mostly defended by Feldman (See Feldman, 2011). Others emphasize revising beliefs while defending conciliationism. The most important dilemma of conciliationism is that it is self-defeating/self-referentially incoherent. As a matter of fact, conciliationists disagree with other views about peer disagreement; therefore after being aware of the disagreement they shouldn't be able to defend their views with the same confidence. Adam Elga, who is a conciliationist, admits that conciliationism is selfreferentially incoherent and there is no good reply for it (Elga, 2010, 182). But Elga notes that "it is in the nature of giving consistent advice that one's advice is dogmatic with respect to its own correctness" (Elga, 2010, 184). Therefore, defenders of conciliationism can also be dogmatic to give consistent advice on resolving the disagreement about disagreement. But isn't it really a problem? If a view does not satisfy its own criteria, doesn't it show that there is a mistake in the criterion? As Kornblith says that "this 
argument is deeply disturbing" (Kornblith, 2013, 274). There is a second big problem for conciliationism. Some say that conciliationism causes scepticism (See Machuca, 2015). This is a troubling result, especially in the areas of philosophy, politics, ethics, and religion. If we follow what conciliationists advice, especially in the disagreements on those areas, we can't have a certain stance. In most philosophical debates we won't be able to fully defend an opinion or will be agnostic. It's no different in politics, religion or ethics.

Second response to a peer disagreement is steadfastness/nonconformism. Defenders of steadfastness argue that disagreement with peers doesn't give a defeater to the disputed belief. Hence, one can maintain his own belief, and this is rational. One of the defenders of steadfastness, Peter van Inwagen says that his attitude is rational in maintaining his beliefs in view of his disagreement with philosopher David Lewis, who has exactly the opposite of his beliefs about the problem of free will. He says that he has unwillingness to admit that David Lewis or himself are irrational. Then, he supposes that he has some sort of interior, incommunicable evidence that Lewis didn't have (van Inwagen, 2010, 23-26). Other nonconformist Foley argues that if he disagrees with someone who is equally well-positioned to evaluate the issue and equally skilled and equally well informed and devoted an equal amount of time and effort to thinking about the issue, he has no reason to defer the other's authority (Foley, 2004, 110111). While he is claiming his opinion, he underlines the idea that trust in our most basic cognitive faculties is a central part of our intellectual lives (Foley, 2004, 24). Also, Zagzebski and Enoch mention the necessity of self-trust in disagreement (See Zagzebski, 2006; Enoch, 2010). Another non-conformist Bergmann argues that if one of the peers has a theory of error according to which the apparent insight that the key ingredients of disputed beliefs are true is not a genuine insight, he can maintain his belief despite peer disagreement because that person will be internally rational. However, Bergmann argues that it is possible that he will also be externally rational. In other words, Bergmann says that there can be a reasonable disagreement between two peers (Bergmann, 2009, 338-342). It seems that defenders of steadfastness view have solved the problem of peer disagreement in their favour, by assuming that they have special evidence that other doesn't have, and by demonstrating the importance of self-trust in their own beliefs, or by defending the rationality of error theory that 
is unique to them. In my opinion, they seem to have tried to solve by breaking the symmetry between them and their peers. As a matter of fact the same situation would be valid for the other party, so they indirectly caused the disagreement to remain unsolved. But, some disagreements can be resolved with non-personal evidence. Just as conformism fails to resolve complex disagreements, steadfastness fails to resolve simple disagreements. However, the steadfastness view is in the right line that there are disagreements that can't be resolved, and that both sides will be rational in maintaining their beliefs in these cases. But steadfastness view is in the wrong line for some cases, cause the determining factor in the resolution of disagreement should be evidences. In other words, it should not be about other party, but about the evidence that we have.

The third response to a peer disagreement is Thomas Kelly's total evidence view. In his view Kelly seeks to find a middle ground between conciliationists and non-conformists about valuing the disagreement itself. Conciliationists place too much value on the disagreement itself, while others do not value it at all. For Kelly, in a peer disagreement between him and his peer, total evidence involves; their original evidence $\mathrm{E}$, the fact that his peer is quite confident that $\mathrm{H}$ is true and the fact that he is quite confident that $\mathrm{H}$ is false. Here, $\mathrm{E}$ is first-order evidence and the other two are higher-order psychological evidences. Kelly argues that; "In some cases, the first-order evidence might be extremely substantial compared to the higher-order evidence; in such cases, the former tends to swamp the latter. In other cases, the first-order evidence might be quite insubstantial compared to the higher-order evidence; in such cases, the latter tends to swamp the former." (Kelly, 2011, 202-204). So what cases? Kelly claims that the number of peers determines what is reasonable to believe. If number of peers is large enough, the higher order evidence will swamp the first order evidence into virtual insignificance (Kelly, 2011, 203). Indeed, a case that the number of peers in disagreement is determining factor with a case that evidence is determining factor doesn't always match. Because there are actually cases where the evidence is extremely strong, no matter how many peers you disagree with. Kelly states that it is possible to have a case in which a large number of peers make the same mistake and reach the same wrong conclusion. If so, he says that in those cases the rational response is not to maintain the belief, even if it is true (Kelly, 2011). This seems to be the weakest point of Kelly's total evidence view. 
Another solution to the peer disagreement is Lackey's justificationist view. To rephrase this view with Lackey's own formulation; in the ordinary disagreement between $\mathrm{A}$ and $\mathrm{B}$, if $\mathrm{A}$ 's belief about $\mathrm{p}$ is provided by high degree justification and A has a symmetry breaker, A can equally rationally maintain his belief. But in the ordinary disagreement between A and B, if A's belief about $\mathrm{p}$ is provided by low degree justification, A must revise his own degree of belief (Lackey, 2010, 319). This solution, which seems quite reasonable at first sight, shows its vulnerabilities with the examples given by Lackey. In Directions, Lackey talks about her disagreement with her neighbour, who moved into the same apartment building an equal amount of time ago, and whom they occasionally meet at the restaurant where they even disagreed over its location. In this example, one says the restaurant is on Michigan Avenue, while the other says it is on State Street. Lackey argues that the right response in this case belongs to the steadfastness view. According to her, this is because she has lived in the city where the restaurant is located for fifteen years, knows the city inside out, eats in that restaurant frequently, has never drank or used drugs, has evidence that her memory is functioning reliably and knows that these are true about her; her confidence for the restaurant's location is perfectly justified, even after her neighbour has fully disclosed his memory of the restaurant being on State Street. Moreover, for Lackey, the disagreement in question can be perceived as evidence that something is wrong with her neighbour. For instance, one may be doubtful about the neighbour that he is a drinker, daydreaming, or suffering from some sort of memory loss; in any case, Lackey is rational in concluding that her neighbour is no longer her epistemic peer regarding the restaurant's location. As is seen, in this case, Lackey does not perceive the disagreement itself as evidence against her own belief, contrary what the conciliationists suggest, and even argues that the disagreement will result in the fact that she is sure that the problem is with the other person. However, in order to adopt this post-disagreement attitude, conciliationists argue that a symmetry breaker is needed against symmetry in epistemic peer. This symmetry-breaker is what will make one epistemic peer superior to the other, and Lackey suggests that if this symmetry-breaker is lacking, her resistance to doxastic revision will seem more likely an attitude than even dogmatic egoism. According to Lackey, the symmetry-breaker is personal information. What she meant is the information one holds for the normal functioning of his/her own 
cognitive faculties. For example, information such as that you are not currently suffering from depression, are not experiencing side effects from prescribed medication, or are not exhausted. But, she may not know that all this information is true for the other person (Lackey, 2010, 309-310). In my view, the first weak point is that the symmetry breaker is far from coming up with a fair settlement between the parties. Another important weak point is that it is not clear that the determining factor of the justification is whether low or high degree. To me, Lackey's personal information is not too different from van Inwagen's private evidence theory, or Foley and Zagzebski's self-trust theory, or Bergman's error theories. In fact, she fails to avoid epistemic egoism with the thought that the problem is with her peer, and this is clearly an expression of prejudice. Therefore, if a criticism is to be made on nonconformists, the same criticism should be made here as well. Most importantly, the degree of justification does not seem to have a decisive element in Lackey. Just as Kelly could not clearly identify the criterion that gives the evidence high degree in his total evidence view, it seems that Lackey could not clearly reveal the criterion that gives the justification high degree.

\section{Uniformity in Peer Disagreement}

In conciliationism and steadfastness, there is only one solution to all types of disagreements. This is uniformity, as defined by Lackey (Lackey, 2010, 302). However, there are also extremely complex disagreements that we encounter especially in religious, political, moral and philosophical disagreements as well as simple disagreements like what the object in front of us is. Kirk Lougheed, one of those who are aware of this problem, puts forward an argument called "The Different Disagreements Argument" and defends the falsity of this generalization approach. According to this argument, there are epistemic differences between cases of disagreement (simple cases provide intuitive support to conciliationism and complex cases provide intuitive support to steadfastnes), and these differences are based on the complexity of the disagreement in question. Complexity is determined by the difficulty of maintaining a coherent set of beliefs in a disagreement, and also by whether it is possible to confirm which disputant is right. Thus, a solution defended in accordance with one type of disagreement does not apply to all cases of disagreements (Lougheed, 2020, 20). 
Here Lougheed makes a distinction between simple and complex disagreements, but in my view right response to a disagreement should be purely case-based. Sufficient attention should be paid to the fact that sometimes there can be cases in which the same disagreement can be resolved in a different way when one of the peers changes. For example, the resolution to be used in a disagreement between non skeptic peers about what an object is; will not be the same when one of the peers is replaced by a sceptic or solipsist who denies the reality of the external world. While this disagreement between non skeptic peers is a simple one at first, it turns into a complex philosophical disagreement when one of the peers is skeptic or solipsist.

\section{The Evidence-based Argument in Peer Disagreement with Sample Cases}

Above, four main responses on the issue of peer disagreement has been mentioned and why they were not successful on solving the problem was explained. Now, I'm going to try to put forward a new argument as a solution how the problem should be tackled with in daily life.

First of all, since my argument is based on evidence, it is useful from my standpoint to consider the concept of evidence. According to some philosopher of religions, such as Reçber, even though the truth of a belief is not directly related to evidence or proof, it is indirectly related; it is only possible to see or show what is right or wrong with proof (Reçber, 2013, 208). However, especially in Islamic literature, there are many types of evidences. Especially, according to the early kalam scholars, evidence is what leads to the truth or the point that is wanted to be evidenced in any matter. Also, kalam scholars classified the evidence in various ways. To set an example, in terms of the source of the knowledge, they divided the evidences as based on reason and on revelation. Similarly, another distinction is in terms of the value of the result they cause and these are conclusive evidence/conjectural evidence. This is the distinction I will use in my argument. In this context, conclusive evidence is evidence that eliminates all of the counter-possibilities regarding the subject it aims to prove; conjectural evidence, on the other hand, is evidence that cannot eliminate all counter-possibilities regarding the subject it aims to prove (Yavuz, 23.06.2021). 
To explain my Evidence-Based Argument after mentioning the concept of evidence, I propose to consider three options in a case of peer disagreement:

In a case of peer agreement,

a) if both peers have conjectural evidence and it is possible to obtain conclusive evidence for a solution, the conciliatory view (based on suspension of judgment) is correct;

or

b) if both peers have conjectural evidence but conclusive evidence is not or cannot be reached, it is rational for the peers to continue to maintain their own beliefs, as in the steadfastnes view;

or

c) if one of the peers has conclusive evidence in comparison with the other, the situation that should occur is that the one with the conclusive evidence continues to maintain his belief, while the other gives up his own belief and agrees fully with the view of his peer.

The evidence-based argument is as described above, but I would like to mention two more significant points regarding the argument that can be misunderstood. The first is what I mean by the possibility of obtaining conclusive evidence in option $a$. It seems that it would be appropriate to put a time-bound on the aforesaid possibility. For instance, in a disagreement regarding the existence of life on a planet, it is possible to obtain a conclusive evidence with the spacecraft to be sent to that planet and the findings it has obtained, but this may take many years. So what would be the correct option in such a disagreement? Therefore, what I mean by the possibility in option $a$ is the process of obtaining evidence that can take a very short time. The second important point is based upon the same example, let's assume that many years have passed and we had conclusive evidence that life exists, then option $c$ will be correct. In other words, as new evidence is obtained in the disagreement, it is possible to switch between the options, and this will enable to reveal that the evidence is the most significant determinant in the resolution of the disagreement.

I will now try to explain my argument with sample cases.

Case 1 (The thing over there):

While the two friends are sitting on a little hill and watching the scene, something moving at a distance attracts their attention. One of the friends 
says that the moving thing looks like a dog, while the other says that it looks more like a sheep. The one who associates the moving thing with a dog argues that sheep usually travel in herds, but because there is only one animal there, it is more likely to be a dog. The other claims that it may also be a straggler sheep, and insists that what appears in shape looks more like a sheep than a dog. In the meantime, these two debating friends spent the whole day together. Neither has more mental fatigue than the other. Also, neither of them used alcohol, drugs, etc. that would affect their mental functioning. Moreover, both have similar past experiences, and neither is more familiar with animals, especially sheep or dogs, than the other. In other words, these two friends are peers in the disagreement in question.

Resolution:

First of all, to analyze the case, both friends have shared evidence to prove their righteousness. While one was talking about that sheep are gregarious animals, the other used the shape of the thing he saw as evidence. Although their evidence is quite reasonable, the two friends were unable to convince each other. In this case, if their curiosity really prevails, all they have to do is to go near the moving thing and make sure what it is. Both friends are not sceptic, accepting the reality of the external world, and indeed, out of curiosity, they see that it is a dog that moves. Now, if we go back to our argument; this case fits for " $a$ ". That is, both peers have conjectural evidence and it is possible to obtain conclusive evidence for the resolution. Here, conclusive evidence is obtained by going near the moving thing and seeing directly what it is in such a way that neither party can deny it. As I explained here in the concept of peer, it is also important to be virtuous, that is, they should be honest enough not to deny the opposite even after seeing it with their own eyes. If necessary, it is possible to solidify the evidence by asking other people who may be present in the vicinity.

As is seen, when we encounter such things in our daily lives, what each of us actually does is probably to concentrate directly on the resolution of the disagreement, as here, and to tend towards the resolution in the hope of obtaining it. Both friends did the same. In such a case, it is not rational for one of the parties to persist in maintaining his own belief, because the disagreement in question is something that can be resolved in a short time. 


\section{Case 2 (Historians):}

Two historians, who received the same education, albeit from different universities, and specialized in the same field, are in disagreement about the underlying causes of a historical event which leaves no room for doubt in history as to its occurrence, but about which there is no large number of documents and data. Let's assume that this is a war. Historians have information about some of the developments before and after the war and how the war took place. One of them says that it is necessary to focus on the developments after the war in order to figure out the cause of the war more clearly; the other argues that the developments before the war are the underlying reason of it and made it inevitable. However, the historical data in hand is not sufficient to fully justify either one.

\section{Resolution:}

In the case, we see that the available evidence is not sufficient to refute all of the counter-possibilities. In other words, there is no conclusive evidence regarding the cause of the war. That's why historians make interpretations on the evidence and there are differences between them. Until a new historical source is found that will doubtlessly reveal the cause of the war, or even if there is no such source, accepting that the historians are peers, it is clear that it would be rational for both to continue their views using the evidence at hand. The important thing here is that both historians establish their own views using the evidence, even if they do not convince the other side.

\section{Case 3 (Shape of the World)}

We have two friends, who are not expert but very interested in astronomy and have had many conversations about similar topics, one of them explains that one day, he learned that there was a group that argued that the earth is flat, that he obtained and examined their arguments, and was convinced, therefore, he now believed that the earth is flat. The other friend is curious and examines the aforesaid arguments, but points out that the evidence demonstrating that the earth is geoid is more conclusive and not convinced due to the supporting data such as flight routes of the planes, the silhouette of the earth falling on the moon, the photographs of the earth taken repeatedly from space and many more points.

\section{Resolution:}

Even though the geoid form of the Earth has been scientifically proven today, there are still people who can be described as conspiracy theory 
believers, who believe that the world is flat, as in the case. However, since the fact that the world is geoid is uncontroversial evidence, in other words, it is conclusive evidence, here both of the disputing friends in the case must have had a definite view that the world is geoid.

\section{Some Additions}

If we consider the cases that are widely discussed in the peer disagreement in terms of evidence-based argument; for instance, option $a$ fits for the Christensen's restaurant case (See Christensen, 2011, 193), because with a calculator we can find the exact result that will settle the disagreement. Or in Feldman's the quad case (See Feldman, 2011, 32), similarly option $a$ applies because the answer to the question of whether there is a dean in the courtyard can be found out by asking the dean later or by going to that part of the quad. A similar situation can be observed in Elga's horse race case (See Elga, 2007, 486) and Lackey's directions case (See Lackey, 2010, 299-300).

I would like to emphasize here again that right response to a disagreement should be purely case-based. If we consider simple disagreements similar to the fact I talked about in case 1, and replace one of the disputants with a solipsist or a skeptic who denies the reality of the outside world, the right option would be option b, not option a.

Also; in disagreements where the result is that both parties maintain their belief, the rationality of both peers does not mean that both parties are right. In other words the truth is always unique, and what is rational does not mean it is the truth.

\section{Conclusion}

In this article, I have discussed one of the most important issues in contemporary epistemology, the problem of peer disagreement. Having explaining the deficiencies in the responses that given to this problem, I put forward a new argument that I think will make up for these shortcomings. In the evidence-based argument in peer disagreement, I used one of the evidence classifications found in the kalam literature: conclusive evidence/ conjectural evidence. With reference to that classification, the evidence we have is a decisive factor of resolution in disagreement. 
Lastly, my argument may be thought as it justifies diversity of views, especially in political, religious, ethical, and philosophical disagreements, and may sound comparable with relativism. But actually, my argument consists mainly of a systematic statement of how, whatever our social status is, should we resolve the disagreements we witness in our lives.

\section{Kaynaklar/ References}

Bergmann, Michael. "Rational Disagreement after Full Disclosure". Episteme: A Journal of Social Epistemology 6/3 (2009), 336-352.

Elga, Adam. "How to Disagree About How to Disagree". Disagreement. ed. Ted Warfield Richard Feldman. 175-186. New York: Oxford University Press, 2010.

Elga, Adam. "Reflection and Disagreement." Noûs 41/3 (2007), 478-502.

Enoch, David. "Not Just a Truthometer: Taking Oneself Seriously (but not Too Seriously) in Cases of Peer Disagreement." Mind 119/476 (2010), 953-997.

Feldman, Richard. "Reasonable Religious Disagreements". Social Epistemology: Essential Readings. ed. Alvin I. Goldman - Dennis Whitcomb. 137-158. New York: Oxford University Press, 2011.

Foley, Richard. Intellectual Trust in Oneself and Others. Cambridge: Cambridge University Press, 2004.

Kelly, Thomas. "Peer Disagreement and Higher-Order Evidence". Social Epistemology: Essential Readings, ed. Alvin I. Goldman - Dennis Whitcomb. 183-221. New York: Oxford University Press, 2011.

Kornblith, Hilary. "Is Philosophical Knowledge Possible?", Disagreement and Scepticism. ed. Diego E. Machuca. 260-276. New York: Routledge, 2013.

Lackey, Jennifer. "A Justificationist View of Disagreement's Epistemic Significance". Social Epistemology. ed. Adrian Haddock et al. 298- 325. New York: Oxford University Press, 2010.

Lougheed, Kirk. The Epistemic Benefits of Disagreement. Switzerland: Springer, 2020.

Machuca, Diego E. "Conciliationism and the Menace of Scepticism”. Dialogue 54 (3) (2015). 469-488.

Matheson, Jonathan. "Disagreement: Idealized and Everyday", The Ethics of Belief: Individual and Social. ed. Matheson J. - Vitz R. 315-330. New York: Oxford University Press, 2014.

Matheson, Jonathan. "Deep Disagreements and Rational Resolution”. Topoi (2018).

Reçber, Mehmet Sait. “Akıl ve İman”. Din Felsefesi. ed. Recep Kılıç, 175-225. Ankara: Ankara Üniversitesi Uzaktan Eğitim Yayınları, 2013.

Van Inwagen, Peter. "We're Right. They're Wrong", Disagreement, ed. Ted Warfield - Richard Feldman. 10-29. New York: Oxford University Press, 2010.

Yavuz, Yusuf Şevki. "Delil", TDV İslâm Ansiklopedisi. Accessed 23 June 2021. https:// islamansiklopedisi.org.tr/delil\#1.

Zagzebski, Linda. "Self-Trust and the Diversity of Religions". Philosophic Exchange 36/1 (2006). 63-77. 